\title{
Emplastus biamoensis nom. n., a replacement name for ant (Hymenoptera: Formicidae) from Bol'shaya Svetlovodnaya (Late Eocene of Sikhote-Alin, Russian Far East)
}

\section{Emplastus biamoensis nom. n. - новое название самки муравья (Hymenoptera: Formicidae) Большой Светмоводной (позАний эоцен, Сихотэ-Алинь, Аахьний Восток, Россия)}

\author{
K.S. Perfilieva ${ }^{1}$, A.P. Rasnitsyn ${ }^{2,3}$ \\ К.С. Перфимьева ${ }^{1}$, А.П. Расницын ${ }^{2,3}$
}

\begin{abstract}
${ }^{1}$ Lomonosov Moscow State University, Leninskie Gory, 1-12, Moscow 119991 Russia
${ }^{2}$ Palaeontological Institute, Russian Academy of Sciences, Profsoyuznaya str., 123, Moscow 117997 Russia. E-mail: alex.rasnitsyn@ gmail.com

${ }^{3}$ Natural History Museum, London, UK

${ }^{1}$ Московкий государственный университет им. М.В. Аомоносова, Аенинские горы, 1, стр. 12, Москва, ГСП-1 119991 Россия ${ }^{2}$ Палеонтологический институт им. А.А. Борисяка РАН, ул. Профсоюзная, 123, Москва 117997 Россия

${ }^{3}$ Музей естественной истории, АонАон, Великобритания
\end{abstract}

Key words: Hymenoptera, Formicidae, Emplastus, new name, Russian Far East, Late Eocene, Radoboj, Miocene. Ключевые слова: Hymenoptera, Formicidae, Emplastus, новое название, Приморский край, эоцен, Радобой, миоцен.

Abstract. Emplastus biamoensis nom. n. is proposed as replacement name for the female ant Emplastus dubius Dlussky, Rasnitsyn et Perfilieva, 2015 from Late Eocene of Sikhote-Alin, Russian Far East, because of homonymy with E. dubius Dlussky et Putyatina, 2014. Comparison of the renamed species with congeners is updated.

Резюме. Новое название Emplastus biamoensis nom. n. взамен преоккупированного преАложено Аля муравья Emplastus dubius Dlussky, Rasnitsyn et Perfilieva, 2015 (non E. dubius Dlussky et Putyatina, 2014) из позАнеэоценовых отложений Приморского края. Аополнено сравнение этого вида с Аругими видами Emplastus.

The name Emplastus dubius has been almost simultaneously proposed for two different ant fossils from different deposits, the Miocene of Radoboj, Croatia [Dlussky, Putiatyna, 2014] and Eocene of Bol'shaya Svetlovodnaya, Russian Far East [Dlussky et al., 2015]. Hence the name Emplastus dubius Dlussky, Rasnitsyn et Perfilieva, 2015 is a junior homonym and so deserves replacement which is provided below. The two species affected with homonymy have not been originally compared: this omission is corrected here as well.

\section{Taxonomy}

\section{Emplastus biamoensis Perfilieva et Rasnitsyn, nom. n.}

Emplastus dubius Dlussky, Rasnitsyn et Perfilieva, 2015: 135 (non Emplastus dubius: Dlussky, Putyatina, 2014: 242); Bol'shaya Svetlovodnaya, Late Eocene of Sikhote-Alin, Russia.
Remarks. Unfortunately the species of Emplastus considered in the two publications in question have left not compared each other, which may cause problems in their identification. To smooth the problem, we provide the comparison. Emplastus britannicus Cockerell, 1915, E. gurnetensis Donisthorpe, 1920, E. dubius Dlussky et Putyatina, 2014, E. haueri Dlussky et Putyatina, 2014, E. miocenicus Dlussky et Putyatina, 2014 and E. (?) ocellus Dlussky et Putyatina, 2014 are all described after the female sex [Cockerell, 1915; Donisthorpe, 1920; Dlussky, Putyatina, 2014]. Emplastus britannicus and E. gurnetensis differ from E. biamoensis nom. n. in having petiolar scale thicker and higher. Scutum is about 1.5 times as long as scutellum in E. dubius and only 1.1 times as long as scutellum in E. biamoensis. Ratio of mesosoma length to gaster length is considerably higher in E. haueri comparing E. biamoensis ( 0.7 and 0.5 , respectively). Occipital margin is concave in E. (?) ocellus and convex in E. biamoensis. Gynes are bigger in E. britannicus, E. dubius and E. miocenicus than in E. biamoensis (body length 6-8.5, 7.5, 13.5 and $5 \mathrm{~mm}$, respectively).

Etymology. After the former name of the type locality (Biamo).

\section{Acknowledgements}

We thank Dr. Matthew E. Clapham (University of California, Santa Cruz, USA) who kindly brought this problem to our attention.

The study was supported by the Russian Foundation for Basic Research, project No. 14-04-00658. 


\section{References}

Cockerell T.D.A. 1915. British fossil insects. Proceedings of the United States National Museum. 49: 469-499.

Dlussky G.M., Putyatina T.S. 2014. Early Miocene ants (Hymenoptera, Formicidae) from Radoboj, Croatia. Neues Jahrbbuch für Geologie und Paläontologie. 272(3): 237-285
Dlussky G., Rasnitsyn A., Perfilieva K. 2015. The ants (Hymenoptera: Formicidae) of Bol'shaya Svetlovodnaya (Late Eocene of Sikhote-Alin, Russian Far East). Caucasian Entomological Bulletin. 11(1): 131-152. Donisthorpe H. 1920. British Oligocene ants. Annals and Magazine of Natural History. 9(6): 81-94. 